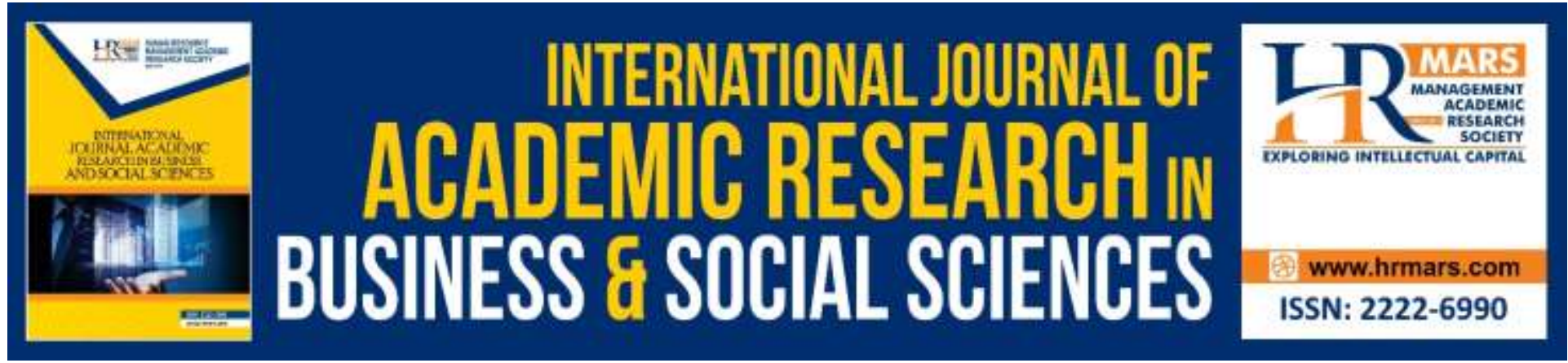

\title{
Contributions of Co-Operative Societies in Economic Empowerment of Rural Women in Abia State
}

\author{
P. C. Okonkwo, C. N. Onyeze, D. I. Ochiaka
}

To Link this Article: http://dx.doi.org/10.6007/IJARBSS/v9-i8/6349

DOI: $10.6007 /$ IJARBSS/v9-i8/6349

Received: 26 July 2019, Revised: 10 August 2019, Accepted: 30 August 2019

Published Online: 03 September 2019

In-Text Citation: (Okonkwo, Onyeze, \& Ochiaka, 2019)

To Cite this Article: Okonkwo, P. C., Onyeze, C. N., \& Ochiaka, D. I. (2019). Contributions of Co-Operative Societies in Economic Empowerment of Rural Women in Abia State. International Journal of Academic Research in Economics and Managment and Sciences, 9(8), 219-236.

Copyright: (C) 2019 The Author(s)

Published by Human Resource Management Academic Research Society (www.hrmars.com)

This article is published under the Creative Commons Attribution (CC BY 4.0) license. Anyone may reproduce, distribute, translate and create derivative works of this article (for both commercial and non-commercial purposes), subject to full attribution to the original publication and authors. The full terms of this license may be seen at: http://creativecommons.org/licences/by/4.0/legalcode

\section{Vol. 9, No. 8, 2019, Pg. 219 - 236}

Full Terms \& Conditions of access and use can be found at http://hrmars.com/index.php/pages/detail/publication-ethics 


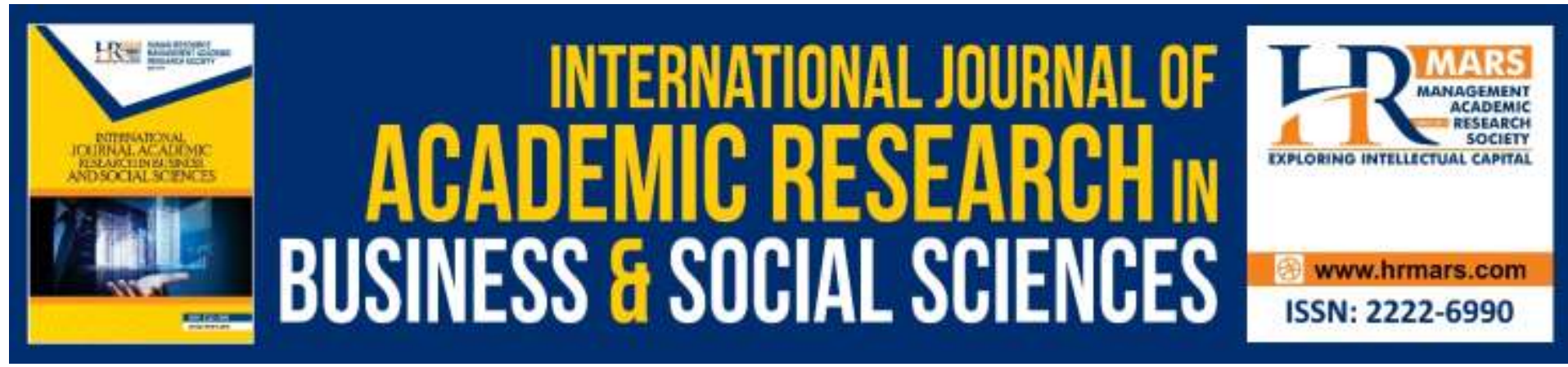

\title{
Contributions of Co-Operative Societies in Economic Empowerment of Rural Women in Abia State
}

\author{
P. C. Okonkwo, Ph.D, C. N. Onyeze, Ph.D, D. I. Ochiaka, \\ Ph.D.
}

Department of Co-operatives and Rural Development, Enugu State University of Science and Technology

\begin{abstract}
As the title indicates, "contribution of co-operative societies in Economic Empowerment of Rural Woman" aims at discussing ways and methods through which co-operative societies can contribute in Economic Empowerment of the rural women. It is unadoptable and undebately that the contribution of the co-operative societies will not only empower the rural women, but will also enlighten them on some aspect of their lives. This work is emphasizing that cooperative societies should focus more on the rural area so the impact of development and empowerment would be integral, i.e a kind of empowerment that will start form the grass root. The general objective of the study is to evaluate the contribution of co-operative societies in economic empowerment of rural women in Ohafia Local Government Area of Abia State. Data collection and analysis were gathered through the use of percentage and table in order to make the analysis very simple and comprehensive. Base on the collection of data I was able to make the following findings: Economic empowerment of rural women is a very important means of improving the general economic condition of the rural women. Women researchers and development centers have found out that 95\% of the surveyed eastern rural women do farming as their primary occupation. However, the following recommendations were made, that government should assist co-operative societies by providing for them those thing they need to perform effectively.
\end{abstract}

Keywords: Co-Operative Societies, Economic Empowerment, Rural Women.

Introduction

Back Ground of Study

Since the beginning of the $21^{\text {st }}$ century Rural Women began to enjoy more freedom and power than ever before. According to Ngash (2000) women are still at disadvantage when they are deprived of equal access to education, health care, capital and decision making power in the political, social business and even in the family.

The world has recognized the vital importance of education as the main aspect of human security and as means to empower rural women; according to United Nation 
Development Programme (UNDP) Report of 2001 women in Africa represent 52 percent of total population contribute approximately 75 percent of Agricultural work and produce 60 to 80 percent of food rural women consume yet they are numbers indicate the challenges women face on their road to gender equality; despite the efforts made in the developing countries like Nigeria, majorities of women are still relegated to micro enterprises etc.

However, there is a wide consensus that industry in the economy empowerment of rural women will help reverse these trends, increase income controlled by women gives them self - confidence which help them obtain a voice and also get to vote in the political, social, business and even in family life. The rural women who control their own income intend having a fewer children because the fertility rates have shown to be inversely related to national income growth.

The co-operatives societies have a very important role to play in the economic empowerment of rural women. Why did I say so? This is because co-operative society is seen as the easiest way of getting to the rural women. And another question I have to ask is, how has the cooperative societies been able to do this for their member. It is because of this back drop that the researcher has undertaking of study all these important object matter.

\section{Statement of the Problems}

Women research and development centre (WORLDOC 1988) has found out that 95 percent of the surveyed eastern rural women do farming as their primary occupation, 74 percent owned or worked on their separate plots yet the rural women are not given the appropriate recognition and because of this, their contribution to the general economic development is under minded.

Many of the co-operative societies do not have all it takes to provide all the services needed by the rural women e.g agricultural loans, training and determination of quality of goods produced. Government and other various agencies handicapped co-operatives societies from their contributions to their members. The question bordering our mind here is that whether the co-operative societies actually contribute to the economic empowerment of their women, if yes how do they go about it and what form of contribution do they make and if no, why? These and more constitute the problem bordering our mind as we undertake the study.

\section{Objectives of Study}

The general objective of the study is to evaluate the contribution of co-operative societies in economic empowerment of rural woman in Ohafia Local Government Area; include:

\section{Specific Objectives are}

1. To identify the types of financial assistance the women in co-operative receive from the societies.

2. To examine the form of training the co-operatives societies render to rural women in agricultural production.

3. To examine the form of assistant co-operative societies render to the rural women to improve their economy. 


\section{Research Questions}

1. What form of financial assistance do the women that are members of the co-operative receive from the societies?

2. What form of training do the co-operative societies give to the rural women in the aspect of agricultural production?

3. What form of assistance do co-operatives societies render to the rural women in the rural areas?

\section{Significance of the Study}

This study is expected to be of good benefit to a very good number of peoples.

Firstly, the finding of this study will enable co-operative societies to understand their role as it regards to economic empowerment.

Secondly, the finding will be very great to the rural women because it will expose all the responsibilities owned to them by their various co-operative societies.

Thirdly, as the economic status of the rural women in Ohafia local government area improves, general economy of the rural area will equal improve considering the fact that women make up over $49 \%$ of the population. The rural areas also contribute to the general economy of the state and that of the national economy.

Lastly, student and the researchers will benefit from this study, to the findings of the study that will take them to some steps offer in the subject matter. It will also serve for them as a reference point in their future studies.

\section{Scope of the Study}

This study was limited to determine the contribution of the co-operatives societies of the economic empowerment of rural women in Ohafia Local Government Area of Abia State.

\section{Review of Related Literature \\ Concept of Economic Empowerment in Agricultural Production}

Agricultural loan is the extension of credits loaned to those involved in agricultural produce. Agricultural has been an important sector of Nigerian economy. It employs about $80 \%$ of the adult working population and earns about $60 \%$ of the gross domestic product (GDP) of Nigerian economy (international food, 2006). This is one of the reasons why the country's economic development policy has been based on the expansion of peasant agricultural production, Olayemi (1980). Manfred (1980), reported that the major constraints to the small - scale farmers improving their farm operations was largely due to restriction to financial access credit facilities.

It is from realization of this critical nature of agriculture that the federal government has come up with the strategy of transforming the economy on improving the rural agriculture. One of the measures is that establishment of the Nigerian agriculture, cooperative and rural development bank (NACRDB), the single largest agricultural development finance institution in Nigeria. NACRDB is one of the efforts of the federal government of Nigeria aimed at boosting the delivery of agricultural development thereby alleviating poverty among the rural and urban poor Nigerians. One of the major constraints small scale women farmers are facing in Nigeria is inability to obtain credit facilities from agricultural production. It is possible that when these conditions are improved upon, the value of small scale women 
farmers' income will meet their expectations that will create enabling environment for the development of economic base of low income women farmers.

\section{Economic Empowerment of the Rural Women through Training}

Training basically addresses intercessions to improve the individuals' knowledge, skill and attitude on the job. Training as a concept implies on awakening of dormant skill, knowledge 9natural, personal and societal) and attitude behavior, character and habits), so that a desired improvement could occur in the performance of ones and it leads ultimately to the development of a new individual and an effective and result oriented business enterprise (CIPM, 2008).

Training the rural women is necessary because it lead to reasonable result in their agricultural business. This is because considering the dynamic natural of agricultural system. Therefore, they need to be trained on the modern system of farming and on how to use the modern tools and equipment for farming.

It is know that rural farmers presently utilize non - mechanized production technologies in their cropping system like the simple farm implements which depend on human energy shifting cultivation instead of activation rotational improved local varieties of crops. They lacked the knowledge of herbicide to control weeds and pests attacks. They use hand and hoe weeding rather than application of herbicides, organic manure rather than fertilizer chijioke (1999). Obibuaku (1983) in support stated that in a traditional sitting, farmers have no knowledge of advanced management techniques or principles. They have little or nothing about input and output calculations, budgeting or other relationship that constitute the financial tools of the commercial form manager.

There is need for change, in all the above mention area of agriculture to effect changes. This attacks the extension agents who are among the agencies of transformation. This significance of low educational level among farmer should be addressed by extension workers. Education is usually value as a means of acquiring knowledge about farm technology. How level of education among farmers adversely affect adoption of innovation: agricultural extension is a system of dissemination information from the research institution to the farmers within the shortest possible time, Trebor (1998) further, rural farmers are trained so as to acquire the necessary skills and knowledge required for the need of innovation.

The agricultural training is needed on the area of increasing crop and vegetable production in educating farmers on how to accept and utilize recommended modern intensive crops and vegetable production, improved breeds of animals. William (1980) for this to be successful, the innovation introduced must be proficient in technical knowledge and educational process and the extension agent must have the right attitude towards rural farmers. The teaching methods and materials to use must vary according to farmers' circumstance and their stances in the various stages of the process.

\section{Empowering Rural Women through Distributing their Goods and Service}

Agricultural co-operative plays an important role in the distribution and marketing of agricultural crops. According to Ezumah and Dominic (1995) co-operative agriculture is a system in which farmers pool their resources; this is usually other an agricultural marketing supply co-operative or an agricultural. Marketing co-operative, supply co-operative purchase service and supplies such as seeds and fertilizers together, while marketing co-operative pool 
their resources for the transformation, prizing, distribution and marketing of produce. World Bank, (2000).

A co-operative structure serves to provide agricultural produce the opportunity to process and market their crops in a joint business venture with other producers, additional benefit of co-operative are:

1. Arranging timing and scheduling of delivery

2. Assigning transportation and delivery cost.

3. Setting delivery location

4. Securing prices.

Agriculture is among the four industries in which co-operative business structures are found. Other types of co-operative are;

1. Consumer goods co-operative,

2. Financial Credit Unions

3. Housing Insurance

4. Rural electric system co-operatives.

These co-operatives business may be owned by consumer, employees business, or by government and nonprofit organization.

Agricultural co-operative may be organized by the function production co-operatives, more commonly found in California. Agriculture permit farmers of organize their farms to cooperative co-operation. Supply co-operation offer the function of providing inputs to processes at competitive prices. While service co-operative produce service to members such as credit, utilities and insurance.

Agricultural marketing co-operative are commonly organized by farm commodity or groups of commodities such as sugar, gain, corn and poultry. Marketing co-operative structures may function as contract and price bargain co-operative or may be involved in processing or manufacturing of specific agricultural commodities.

There are some very general reasons for forming agricultural co-operatives. Most of the reasons permit analysis for determining the effectiveness of one co-operative as a method of marketing agricultural produces. Agricultural co-operative are formed to solve market failure. Market failure occurs when goods are not distributed to the benefit of all reasons involved in market. In particular two instances characterize market failure. First, large number of buyers and seller may fail to enter the market. Secondly, equilibrium price may never be reached because market prices are too high, which may adversely affect the sellers or buyers respectively. By solving market failure, farming and commodity systems become more economically efficient (Agbo, 2002).

Co-operatives are also formed to achieve market power or to influence terms of trade. This trade may take the form of domestic or international markets. Terms of trade relate to price, timing, form and other quality or quantity specifications. Agricultural co-operatives are formed by commodity producers.

Variable and fixed inputs cost and capital investment play roles in kinds of decisions. Farmer marketing or supply co-operatives are commonly formed to provide new or missing services. A good example is development of fertilizer blending co-operative, a phenomenon that occurred as a result of farmer producer demand for custom fertilizer bund ratios based on soil and crop analysis. (Onweremadu, 2010)

A major local or regional challenge is co-ordination of the flow of supplies to farmers, such as, fertilizer and chemicals or the flow of farmer product form the farm to processing 
facilities. Grain elevator co-operatives are good example of effective co-ordination of flow of quantities and quality of grains. Rather than expecting farmers to assume the entire development of market for specific crops. Co-operative serves the function of sharing rise among co-operative owner member. This risk sharing plays an important part in development of farm enterprises and developing markets.

Furthermore, a very critical role, although not traditional played by co-operatives, is in the public policy making arena. By influencing public policy, but not to the extent that these influences unduly enhanced price and agricultural co-operatives could play a very strong role in influencing agricultural policy in addition to environmental and energy policy.

\section{Empowering Rural Woman through Determining of the Quality of Goods Produced}

The quality of a product is one feature that determine the acceptability or otherwise of a product. Quality is a feature which marks the standard of a product.

There are vital deficiencies associated with the traditional cropping system among which are low productivity caused by the use of outdated production techniques and tools coupled with the conservative attitude of the rural farmers. This is more so when they exist a wide range of innovation, yet the productive level of farmers appears to be 20 years behind established potentials, (Abalu and Atala, 1982) in order to raise the aggregate production and this make agricultural system viable for the rural farmers.

It is necessary to transform the traditional system of production into modern enterprise it is also necessary to improve productivity to meet the popular food need and equally enrich the national economy. This demands increase in the se of improved inputs and improved varieties of crops and employment of improved method of production (Famoriyo 1998)

Jague and patel (1980) noted that the use of radio and literature in Gambia had positive relationship with package adoption scores and size of grounduely farm and social participation had negative relationship.

According to Okorie (1981) goat mile and sheep are sweet, nourishing and medicinal. Their meats are very rich in protein. However, their Steen and hair attract high export value and used in maintaining soil fertility. These mate sheep and goat production significantly important.

Okorie (1983) opines that in Nigeria, there are two types of houses, one is a large home divided into pens with the central passage way, while the other is portable house which is used where the semi intensive system or the tree range system or the tree range system is practiced. The animals are allowed out in also increase production.

On feeding Ogele, (2006) citing Devendra and Burns (1980) asserted that there is considerable evidence that goat is exceptionally efficient at digesting crude fiber. It is equally documented that goat need acculose in the farm of grass, hay silage or straw and areal mixture feed according to the body weight with extra feed given to lactating growing and pregnant goats. They require a greater maintenance ratio because they high metabolic rate when allowed on their extension situation, they will maintain themselves by grazing because of their browsing method of feeding.

During confinement, feeding becomes imperative with well balanced feed or rotation in the form of concentrates, protein, energy, vitamins and minerals familus, (1970).

According to Umali (1994) training is needed in supply of farm equipment live stock and rending venturing service information. 
Further more Ubi, (1978) reports that he has seen many farms either ploughed and not plant due to shortage of seeds, poor distribution of fertilizer and poorly managed or in most cases not even harvested due to scarcity of labour or harvesting equipments. In some cases, the crops are harvested but not processed, until the quality determines below human acceptability.

Onyenugi, (1987) found that afflictions which befall Nigerian farmers are those using their own United energy to produce the nation food. This is detrimental and most diversitating. He further maintained that the introduction of machines into farm operations in Nigeria would carry advantage with it. More man power and technological resources would be devoted to increase the countries agricultural productivity and expansion of agro - based industry in our country mechanical weed control using tractors including buffalo drawn crop production.

In terms of planting and harvesting processing of crops the extension agents should educate and disseminate the innovation or improved machineries available through organization of seminar, group discussion or practical demonstration of such equipment facilities.

These include spraying diesel for pumping water from the irrigation, ridges, planting machines, Williams (1987) the adoption of innovation techniques or the recommended practices on farm mechanized equipment and implements without doubt maximize output on food production.

\section{Theoretical Framework}

The researcher has selected the feminist theory after careful consideration and critical thinking. As a theoretical framework suitable for the study; providing the necessary support rationale and justification for this study. A theoretical framework is a broad umbrella made up of theoretical postulations (theories, perspective, models or paradigms) that researchers or writers can utilize as guides for understanding or analyzing a reality or phenomenon under study.

\section{Feminist Theory}

The feminist theory aims to understand the nature of gender inequality. It examines women's roles, experiences, interests, and feminist politics in variety of fields, such as anthropology and sociology, communication, psychoanalysis, economics, literature, education and philosophy. (Chodorow, 1991).

Feminist theory focuses on analyzing gender inequality. Themes explored in feminism include: discrimination, objectification (especially Sexual Objectification), oppression, patriachy, (Gilagam, 1977), and contemporary arts (de Eghor, 1996), (Armstrong, 2006) and anesthetics (Arnold, et al, 2003), (Flourence, 2000).

\section{History of Feminist Theory}

The feminist theories first emerged as early as 1794 in publications such as "A Vindication of the rights of women by Mary Wollstonecraft", "The changing woman" (Navago, 2005). The history of the modern western feminist movement is however divided into three "waves (Humm, 1995). Each wave dealt with different aspects of the same feminist issues.

First wave feminist critiques comprised women's suffrage movements of the 19th and early 20th centuries, promoting women's right to vote. 
Second wave (gyno-criticism), was associated with the ideas and actions of the women's liberation movement beginning in the second wave however campaigned for legal and social equality for women. Third wave "gender theory", was a continuation of and a reaction to the perceived failures of second wave feminism, and it began in the 1990s. (Krolokke, 2005).

\section{Empirical Review of the Study}

In a journal paper on "An Assessment of Participant of Rural Women in Community Based Development Activities" presented by Adisa (2013) he conducted a research using structured interviewed schedule to carried out data for the study. The study revealed that average age of rural women participating in community based development activities (CBDA) was 47.9 with standard deviation of 9.0. This implied that the many of the respondents were middle aged and active; this could enable them to participate actively in CBDAs. He concluded that the relevance of rural women as a stakeholder in community-based development activities as a way of attaining and sustaining national development. Achieving sustainability at the grassroots level calls for active participation of women in all aspects of planning, decision and execution of community-based project(s).

Osadebe (2013), in a study on "Women Empowerment and Community Development" opines that the research was carried out with the use of well structured interview schedule to obtain the necessary data. The study revealed that women are actors in solving the major issues on the development agenda for the coming century, including the need to manage the environment in a sustainable manner, the exploding rate or population and urbanization, food security, human needs with regards to health education and literacy and also the elimination of poverty in the society.

Sabo (2005) states that women play a significant role in agriculture, the world over. About $70 \%$ of the agricultural workers, $80 \%$ of food producers, and $10 \%$ of those who process basic foodstuffs are women and they also undertake 60 to $90 \%$ of the rural marketing. Thus making up more than two-third of the workforce in agricultural production. They undertake various activities in agriculture such as cleaning of fields, field preparation, sowing, intercultural practices, weeding, harvesting, picking, cleaning of grains, drying of grains etc. But it is unfortunate that they remain invisible workers. The data were analyzed using appropriate statistical tools. Primary data were collected using a structured questionnaire administered to 90 women in agriculture (WIA). Analysis of the data indicated that $52 \%$ of the respondents were within the age range of 31 to 40 years and about $90 \%$ were married. Some $52 \%$ of the women farmers had at least primary education and $34 \%$ had farming experience ranging from 16 to 205 years. Average family size of the respondents ranged between 5 and 10. Although the WIA programme has led to an increase in agricultural production and income level of the participants, correlation analysis showed a negative relationship between marital status and agricultural production level. The study concluded that the WIA programme had a positive impact on the standard of living of the participants and their family members.

\section{Research Design and Methodology}

In this chapter, discussion will be based on the methodology adopted in carrying out this study. The focus will be centered on the specification of procedures for collecting and analyzing the data necessary. The necessary data include: Design of the study, Area of study, 
Population of study, Instrument method, Validity of Instrumentation and Reliability of Instrumentation.

\section{Design of the Study}

The design used for this research work was the survey design. Under this design, the research used the questionnaire to elicit information from the subject of the study which where the true representative of the population.

\section{Area of Study}

The research area of study was carried out in Ohafia Local Government Area of Abia State. Ohafia Local government Area is about $725 \mathrm{~km}$ 's with the population of 528.695 according to the 2006 National census and it was created in the year 1975 .

The Ohafia Local Government Area is made up of twenty six communities which are listed below. Ebem is the local government headquarter. The communities are; Abia, Akanu, Amuekpu, Amankwu, Amuke, Amuma, Asaga, Ebem, Elu, Eziafor, Ihenta, $1^{\text {st }}-$ ugwu, Nde uduma Awoke, Nde Anya orie, Nde Anku, Nde Amogu, Nde ibe, Nde Okala, Nde Orieke, Nde uduma ukwu, Nkwobi, Oboro, kagwe, Okon and Ufiele.

The people of Ohafia Local Government Area are peaceful and resourceful men and women whose role in the nation is building dates back to the pre - colonial period with Agriculture as their main occupation. The twenty six towns that make up the local government supplies varieties of agricultural predication. Ranging from yam, garri, vegetable, cocoyam and palm oil in commercial quantities, to majority of middle men traders. Who came from far and wide across the nation to buy these items and in turn, helped in no small amount to boast the economy and finance of the people. A particular note was taken about Ohafia local government area being one of the largest cassava production. In addition to other food items, some people from other neigbouring villages come to buy the cassava in large quantity which they use in producing garri and other things.

Men and women in Ohafia local government are distinguished themselves in various fields of human endevour. In Ohafia, they have best in medical aspect and also high professional such as lecturers, teachers, nurses and among other jobs like hunting, wine trapping and tailoring. And when it comes to their occupation, they are good at that and even do more to satisfy their customers.

And also, I will like to tell you that the people of Ohafia shares the same bamder with the people of Abiriba.

The people of Ohafia local government area have a monolittic cultural identify. They are also noted for their deep affiliation to cultural activities in the following area; war dance festival, Iriji festival, Igba uche festival and igwa mang. And festivals are been celebrated within a particular period of a year.

\section{Population of Study}

The population of this study was targeted at the various co-operative societies in Ohafia Local Government Area. According to records, there were 47 registered co-operative societies in the study area. But it is pertinent to note that out of 47 registered, only 38 are active and operational, these 38 active societies have total members of 1560 which comprise of 960 women and 600 male. 
And out of the 38 functional co-operative societies in Ohafia local government area, the researcher using simple random technique selected to societies from this study. The whole 38, randomly picked from a basket, total of which 10 societies were picked. This method gave the whole societies equal opportunity to be selected as shown in the table shown below.

Table 1. The list of the societies selected

\begin{tabular}{|l|l|c|c|}
\hline & NAME OF THE SOCIETIES & $\begin{array}{l}\text { TAG } \\
\text { NUMBER }\end{array}$ & $\begin{array}{l}\text { TOTAL NUMBER OF } \\
\text { THE MEMBERS }\end{array}$ \\
\hline 1. & Udoka yam production co-operative societies & 005 & 20 \\
\hline 2 & Ebem multi - purpose co-operative societies & 014 & 35 \\
\hline 3 & Kalu fishery co-operative societies & 028 & 45 \\
\hline 4. & Dwain farms co-operative societies & 030 & 40 \\
\hline 5. & Dynamic rice co-operative societies & 001 & 30 \\
\hline 6. & Uduma piggry co-operative societies & 022 & 20 \\
\hline 7. & Ezechukwu multi - purpose co-operative societies & 034 & 79 \\
\hline 8. & Akachukwu multi-purpose co-operative societies & 007 & 50 \\
\hline 9. & Ifunaya Palm kennel co-operative societies & 010 & 20 \\
\hline 10 & Ogidi Garri co-operative societies & 017 & 60 \\
\hline & TOTAL & & 399 \\
\hline
\end{tabular}

Source; Field Survey, 2018

\section{Sample and Sampling Techniques \\ Due to the time and financial}

Due to the time and financial constraint, the researcher decided to study the population in the 10 societies because of the relatively small size of the societies that was picked.

The sample size of this study is 399 members of the 10 selected co-operative societies in Ohafia Local Government Area.

\section{Method of Data Analysis}

The researcher used figures, table and percentage in analyzing and interpreting data collected from primary and secondary sources. Table were used in marketing the finding on belief that the higher the percentage the higher the chance of obtaining an accurate and reasonable result.

\section{Data Presentation}

The researchers present the result of their study in which the data collected are organize, presented and analyzed according to the order of the four research question. The researcher employed the use of percentage and table necessary in order to make the analysis very simple and comprehensive.

A total number of one thousand five hundred and sixty (1560) where discussed form the co-operative in Ohafia Local Government Area. Three hundred and ninety nine (399) constitute the sample size. Therefore (399) question only 350 questionnaires were completed and returned making a percentage of $91 \%$ while the total of 49 questionnaire were not returned and it is demonstrated with the table below 
Table 2 Returned Questionnaires

\begin{tabular}{|l|l|l|l|}
\hline Population of the societies & $\begin{array}{l}\text { Questionnaire } \\
\text { Returned }\end{array}$ & $\begin{array}{l}\text { Questionnaire } \\
\text { not returned }\end{array}$ & Percentage \\
\hline 399 & - & 49 & 10.8 \\
\hline & 350 & - & 89.2 \\
\hline & 350 & 49 & 100 \\
\hline
\end{tabular}

Source: Field Survey, 2018

The table above indicate that $10.8 \%$ of the questionnaire where not returned while $8.2 \%$ of the questionnaire where successfully returned.

Table 3 Marital Status Distribution for Respondents Base.

\begin{tabular}{|l|l|l|}
\hline RESPONSE VALUE & NUMBER OF RESPONSE & PERCENTAGE \\
\hline Married & 144 & 41 \\
\hline Single & 91 & 19 \\
\hline Widow & 115 & 40 \\
\hline Total & 350 & 100 \\
\hline
\end{tabular}

Source: Field Survey 2018

The table above shows that $41 \%$ of the members are married, $19 \%$ are single and $40 \%$ are widows. Therefore widows are in majority.

Table 4 Distribution of Respondents Based on their Occupation

\begin{tabular}{|l|l|l|}
\hline RESPONSE VALUE & NUMBER OF RESPONSE & PERCENTAGE \\
\hline Civil servant & 118 & 20 \\
\hline Farmers & 167 & 62 \\
\hline Traders & 65 & 18 \\
\hline Total & 350 & 100 \\
\hline
\end{tabular}

Source: Field Survey 2018

The table above, shows that $20 \%$ of its members where civil servants, while $62 \%$ where farmers and $18 \%$ of its members where traders. Therefore indicates that farmers are its majority members.

Table 5 Age Distribution of Respondents

\begin{tabular}{|l|l|l|}
\hline AGE GROUPING & NUMBER OF RESPONDENT & PERCENTAGE \\
\hline $18-28$ & 35 & 5.7 \\
\hline $29-38$ & 70 & 9 \\
\hline $39-48$ & 80 & 36 \\
\hline 4958 & 60 & 13.8 \\
\hline $59-68$ & 75 & 30 \\
\hline 69 Above & 30 & 6 \\
\hline Total & 350 & 100 \\
\hline
\end{tabular}

Source: Field Survey, 2018

The table above, indicate that $5.7 \%$ of its members where between the age $18-28$, while 98 are from $29-38,365$ where from $39-48$ and $13.3 \%$ where from $49-58$ and 305 where from $59-68$ and the last of them is $6 \%$ where from 69 and above. Therefore, it shows that the majority of its members are from the age of $39-48$. 
Table 6 Distribution of Respondents Based on the Level of Education

\begin{tabular}{|l|l|l|}
\hline RESPONSE VALUE & NUMBER OF RESPONSE & PERCENTAGE \\
\hline None & 87 & 15 \\
\hline Primary & 98 & 44 \\
\hline Secondary & 95 & 36 \\
\hline Tertiary & 70 & 6.5 \\
\hline Total & 350 & 100 \\
\hline
\end{tabular}

Source: Field Survey 2018

The table above indicates that $13 \%$ of the member has no form of education, while $44 \%$ only have a primary education 36 has a secondary education and 6.5 have the tertiary education. This shows that many of its members have only primary educational level, having the highest percentage as $44 \%$.

Table 7 Distribution Base on the Financial Assistance from the Co-Operatives Societies in Ohafia Local Government

\begin{tabular}{|l|l|l|l|}
\hline & RESPONSE VALUE & $\begin{array}{l}\text { NUMBER } \\
\text { RESPONSE }\end{array}$ & OF \\
\hline 1 & Co-operative society loan & 110 & 36 \\
\hline 2. & Agricultural bank loan & 48 & 20 \\
\hline 3. & $\begin{array}{l}\text { Government loan through FADAMA } \\
\text { project }\end{array}$ & 70 & 24 \\
\hline 4. & Micro finance Bank loan & 54 & 10 \\
\hline 5. & $\begin{array}{l}\text { Nongovernmental organizational } \\
\text { loan }\end{array}$ & 60 & 10 \\
\hline & Total & 350 & 100 \\
\hline
\end{tabular}

Source: Field Survey 2018

From the table above, 110 respondents represent $36 \%$ of the total respondent which indicate that they source their loan through co-operative society loan. 48 respondents representing 205 for the total respondent source their loan through agricultural bank loan and 70 respondent representing $28 \%$ source their loan through government loan through FADAMA project. 54 respondent representing $10 \%$ of the total respondents source their loan through micro finance bank while 60 respondents to represent $10 \%$ source their loan through non- governmental organization. 
Table 8 Distribution Base on the Training Programme in the Council

\begin{tabular}{|l|l|l|}
\hline RESPONSE VALUE & NUMBER OF RESPONSE & PERCENTAGE \\
\hline $\begin{array}{l}\text { Book keeping and } \\
\text { accounting }\end{array}$ & 83 & 208 \\
\hline Use of insecticide & 50 & 14 \\
\hline $\begin{array}{l}\text { How to use mechanized } \\
\text { equipment and implement }\end{array}$ & 43 & 12 \\
\hline $\begin{array}{l}\text { Modern system of farming } \\
\text { technique }\end{array}$ & 34 & 248 \\
\hline $\begin{array}{l}\text { Modern system for storage } \\
\text { and food preservation }\end{array}$ & 90 & 30 \\
\hline TOTAL & 350 & 100 \\
\hline
\end{tabular}

Source: Field Survey 2018

From above table, 33 respondent representing $20 \%$ of the total respondents indicate that they acquire training programme on book keeping and accounting skill. 50 respondent representing 148 indicate that they also acquire the use of insecticide. 43 respondent representing $12 \%$ indicate that they acquire the use of mechanized equipment and implement. 90 respondent representing 305 indicate that they acquired modern system of storage and food preservation and 34 respondent representing 248 indicate that they acquired modern system of farming technique through the training programme organized by the co-operative societies in Ohafia local government area. And this shows that many of the members focused on modern system of storage and food preservation and that made it the highest percentage of $30 \%$.

Table 9 Distribution of Respondent Base on the Assist the Rural Women Get from their Cooperative

\begin{tabular}{|l|l|l|}
\hline RESPONSE VALUE & NUMBER OF RESPONSE & PERCENTAGE \\
\hline Providing transportation & 90 & 29 \\
\hline $\begin{array}{l}\text { Connecting members with } \\
\text { the buyer }\end{array}$ & 25 & 8 \\
\hline $\begin{array}{l}\text { Subsidizing cost of } \\
\text { distribution }\end{array}$ & 162 & 43 \\
\hline $\begin{array}{l}\text { Bargaining and fishing price } \\
\text { for their produce }\end{array}$ & 41 & 10 \\
\hline $\begin{array}{l}\text { Patronage of member on the } \\
\text { goods and services }\end{array}$ & 32 & 10 \\
\hline Total & 350 & 100 \\
\hline
\end{tabular}

Source: Field Survey 2018

The above table, shows that 90 respondent is representing $29 \%$ indicate that they will provide transportation while 25 respondent that is representing 85 indicates that they connect their members with the buyer. 162 respondent representing $43 \%$ indicates that subsidizing cost of distribution and 41 respondent that is representing $10 \%$ indicate bargaining and fixing price for their product and lastly 32 respondent that is representing $10 \%$ indicate patronage of member on the goods and service. 
Table 10 Distributions of Respondents Based on the Assistance Co-Operatives Societies Give to their Rural Women in Determining the Quality of their Product.

\begin{tabular}{|l|l|l|}
\hline RESPONSE VALUE & NUMBER OF RESPONSE & PERCENTAGE \\
\hline $\begin{array}{l}\text { Education and training for } \\
\text { high quality produce }\end{array}$ & 110 & 33 \\
\hline Improved farming system & 48 & 12 \\
\hline $\begin{array}{l}\text { Use of fertilizer and } \\
\text { insecticide }\end{array}$ & 70 & 25 \\
\hline Supply of improved seed & 54 & 15 \\
\hline $\begin{array}{l}\text { Use of vetenary service to } \\
\text { provide medicine for their } \\
\text { animals }\end{array}$ & 60 & 14 \\
\hline TOTAL & 350 & 100 \\
\hline
\end{tabular}

Source: Field Survey 2018

From the table above, 110 respondent representing 33\% indicate education and training for high quality product. 48 respondent that is representing $12 \%$ indicate improving farming syste.70 respondent representing 265 indicate the use of fertilizer and insecticide and 54 respondent representing $15 \%$ indicates that the supply or improved seed and 60 respondents that is representing $14 \%$ indicate the use of vetinary services to provide media for their animals.

\section{Summary of Finding}

The findings of this study with regards to the contributions of co-operative societies in the empowerment of rural women revealed the extent to which the co-operative societies were able and they contributed to the economic empowerment of their rural women. Form the data collected and analyzed on the previous chapter, the respondents affirmed that the rural women were given the necessary support they needed.

The various forms of economic empowerment of rural women enhanced the wealth and well being of the nation. This is because women who control their own income tend to impact on their families positively in conjunction with the FADAMA project. The finding agreed with that of Nagish (2006) who revealed that adequate training were necessary in improving the well being of rural women.

The result of the study with regards to assist in the distribution of goods and services showed that to the extent to which the co-operative societies were able to help the rural women to ensure effective distribution of their goods and services. Such services ranged from provision of training superstition, connecting to the buyers, and identifying the markets. The findings agreed with that of world bank (2000) which indicated that agricultural co-operatives pool their resources together for the transformation, packaging, distribution and marketing their produces.

Further more, the result of that which regards to assistance given to rural women in determining the quality of goods they produce. Result showed that the co-operative societies were trying their best in helping their members. The result of the study with respect to cooperative societies in Ohafia local government area shows that they provide financial assistance to the rural women, and also found out that the co-operative assisted the women with direct loans, as well as assisting them to obtain loan from agricultural and co-operative 
banks, government, a world bank assisted poverty alleviation (FADAMA PROJECT) and the micro finance banks even though the credits are not enough. The finding agreed with that of Gana etel (2009) who stated that government and nongovernmental organization need to seek to promote empowerment of rural communication through rural micro fiancé to reduce or eliminate poverty especially rural women.

The result of the study with regards to the forms of training programmes, co-operative societies in Ohafia local government area provide for the rural women, but to the extent to which co-operative societies can offer. These training programmes were sometimes provided in order to enlighten the rural women on how to awakening their skills and knowledge on personal and societal and attitude on thing. And the farming programmes were sometimes provided in order to enlighten them on how they will improve in the agricultural business and how reasonable result they will get when they apply the things that they were been thought in practices. And such training was ranged from book keeping and accounting skill, use of insecticide, how to use mechanized equipment and implement, modern system of farming technique and modern system of farming technique and modern system of storage and food preservation. These were the training that the co-operative societies gave to the rural women in order to ensure quality of their product. This they did by ensuring that members are using the high and improved farm inputs fertilizers, insecticide, use of modern storage and processing techniques as well as undergoing education and training on the modern farming methods. The finding agreed with that of Palmoriyo (1980) who opined that increase in the use of improved inputs and improved varieties of crops and employment of improved methods of production ensured improved quality of product.

\section{Recommendations}

Based on the findings of the study, the researcher wish to make the following recommendation:

1. The co-operative societies should put more effort in assisting their members i.e the rural women in most cases in securing loan for them.

2. They should always organize moral training and educational programmes for their members. This will go a long way in helping them to improve in their performance.

3. Assisting the rural women in the distribution of their goods and services will serve as a serious boost for them in their operation since it is necessary for their member, co-operative societies should help their members in distributing their goods and services.

4. Co-operative societies should also help their members by training them on how to improve the quality of their produce. This will ensure food security.

5. Government should assist the co-operative societies by providing for them those things they need to perform effectively

\section{Suggestion for Further Studies}

Based on the finding form this particular work, the following topics were advanced for further studies.

1. Contribution of non-government organization in the economic empowerment of rural women.

2. Contribution of co-operative societies in promoting economic activities in Afiaigbu Education zone of Abia state.

3. The role of government agencies in the economic empowerment of rural women. 
4. Contribution of agricultural co-operative societies in improving food production.

\section{Conclusion}

Empowering the rural women economically would go a long way in redressing a lot of the societal vices and also help to reduce the spread of HIV/AIDS. The co-operative societies are the headrest and the best means of reaching these rural women since it provided them the way to interact freely.

The study revealed that the co-operative societies in Ohafia local government area as in every part of Nigeria was challenged greatly by inadequate funding and inadequate formed education.

\section{References}

Agbo, D. O. (2002) 'Impact of Agricultural extension Agent in educating farmers on the adoption of innovation in Ohafia Local Government of Abia State' a project submitted to the Department of Co-operative and Rural Development Faculty of Management Science. ESUT.

Aboju, G. O. I. and Atal, T. K. (1982) "Political stability and Agricultural Development, The Role of the Green Involution strategy in Nigeria" paper presented at the National conference on problems of political stability in Nigeria and the future of the second republic, institute of Administration $26^{\text {th }}-30$ April, Ahmadcl Bello University, Zaria.

Atati, Y. K. and Abdullahi, Y. A. (1988). 'Adaption Behaviour of present farmers with regard to improve cropping system. A case study of Northern Nigeria. Proceedings of the Nation farming system' research network workshop held $10^{\text {th }}-13^{\text {th }}$ may in Jos plateau State.

Abi, E. S. (1990) "A note on agricultural extension Rural sociology" Lagos education Itd.

Barton, D. (1989) Co-operative in Agricultural Practice. Enugu wood clift hall.

C.T.A. (2008) "Extension Services Master on Servant" Abi monthly Bulletin of the Technical centre for Agriculture and Rural co-operatives.

Chijioke, R. N. (1999) "A Survey of the Adoption of Improved Technologies by Rural Farmers on Selected Crops, ishiagu" unpublished HND thesis federal college for agriculture, ishiagu Ebonyi state, chattered institute of personnel mangment.

CIPM (1999) "A survey fo the adoption of improved technologies by rural farmers on selected crops" ishiagu, unpublished HND Husis, federal college of agriculture, Ishiagu Ebonyi State.

Erobor, O. (1998) Comprehensive Agricultural Science for Senior Secondary School; lagos. Johnson, publishers Itd.

Ezumah, N. N., and Dominico, C. M. (1995) "Enhancing the role of women in crop production; study of igbo women in Nigeria", world development publisher abuzaria.

Farmiriyo, O. A. (1986) Agricultural Research Administration in Nigeria, science and public policy Lagos; educational Itd.

Famistlas, E. A. (1990) Nigeria Artificate in Education Series Akure, printed in Nigeria by joolad industrial enterprises.

Gana, J., Ajimola B., and Tagbo. (2009) Empowerment of Rural communities study of Igbo women in Nigeria world development. Kaduna Published, ABU Zaria.

Hewitt, P. A., and Labbot. (1982) Agricultural science for school certificate and colleges Ibadan; Gmanado publishers. 
Ibe, L. C. (1990) Agricultural Extension in Tropics London; Mac Million publishers.

Jagne, T. N., and Patel, A. U. (Dec. 1981) "Adoption of Industrial and packaging of improved practice by package non - package groundnut farmers in Gambia' the journal of agricultural extension Abu Zaria.

Negash, A. (2000) Economic Empowerment of Women Global Leadership and ethics markeule; centre for applied ethic press.

Nnoyelu, C., and Godzama, E. (1991) Effective Role for women in Agricultural: support strategies; women in Agriculture sub programme, Ibadan flash press

Olayemi, J. K., and fred, M. D. (1980) Food Crop Production by Small Scale Farmers Targets Rural Development Ibadan, published by university press.

Onweremadu, P (2010) Manpower Development in Nigeria; Enugu: John jac publishers.

Okerie, J. U. (2002) A Guide to Live Stock Production in Nigeria, London Macwill an education Itd.

Olaitan, S. O. (1986) Agricultural Education in Tropics London macmillan publishers Itd.

Onyenuga, U. A (1980) The challenge of 1980's in Nigeria African Nigeria, Ibadan, educational publishers Itd.

Soyebo, K. O. (2005) "A Study of Rural House Hold Resources Management in Osun State; Nigeia" An unpublished PH.D Thesis, Obafemi Awolowo University, Ile Ife. 